UDC 336.14

http://doi.org/10.21272/mmi.2018.4-33

JEL Classification: H30, H72, E62, 047

Tetiana Vasylieva,

D.Sc., Professor, Sumy State University, Ukraine

Yuriy Harust,

D.Sc., Associate Professor, Sumy State University, Ukraine

Nataliya Vinnichenko,

D.Sc., Associate Professor, Sumy State University, Ukraine

Alina Vysochyna,

Ph.D., Sumy State University, Ukraine

\title{
OPTIMIZATION OF THE FINANCIAL DECENTRALIZATION LEVEL AS AN INSTRUMENT FOR THE COUNTRY'S INNOVATIVE ECONOMIC DEVELOPMENT REGULATION
}

Abstract. This article generalizes arguments and counter-arguments within the scientific discussion regarding the determination of the optimal decentralization level, which will provide the country's innovative development, since the key task of decentralization has to be not only to expand the income and expenditure powers of the subnational formations but also to understand the final goal of this process - qualitative transformation of the country's economic system towards improving its innovativeness and competitiveness. Thus, the decentralization reform has to be the driver of the innovative economic development, which is the expected result of the managerial decision-making freedom increase at the local level, the subnational formations' financial self-sufficiency increase and more effective spending policy (expansion of the innovative projects financing amounts that will promote the sustainable economic growth). Systematization of the scientific works on the above problems proves that there is no one idea regarding the decentralization impact on the country's economic and innovative development among scientists. That is why it is urgent to continue the empirical searching in this area, that will enable to take into account the dual nature of consequences regarding the activation of the decentralization processes. The empirical study is carried out through using of the non-linear analysis form of dependence (GLM regression, which enables to identify the linear and nonlinear character of the relationship between variables) based on the panel data, formed for set of 23 states-OECD members (Austria, Belgium, Canada, the Czech Republic, Denmark, Estonia, Finland, France Germany, Greece, Hungary, Italy, Netherlands, Norway, Poland, Portugal, Slovakia, Slovenia, Spain, Sweden, Switzerland, Great Britain and the USA) during 2002-2015. The expenditure decentralization index, calculated as the ratio between the consolidated expenses amount at the subnational level and state consolidated expenses, expressed in parts of the whole, is chosen as the factorial variable model. The final variable (traditional for the economic growth models) is GDP per capita (dollars the USA). Besides, the set of control variables is added to this regression model (which explain the regularities of the resultative feature change and have a strong relationship with it). The control variables are selected on the basis of correlation analysis. The practical implementation of all stages in this research is performed using the software product Stata 12/SE. The results of the study confirm the non-linear character of dependence (the inverse U-shape) regarding the GDP change per capita on the expenditure decentralization level change, and also the maximum extremum of the function in the point with expenditure decentralization level 1.35. It means that excessive expenses load (above the specified norm) on the local budgets will be accompanied by inhibition of the innovative and economic dynamics, that should be taken into account by the relevant authorized executive bodies in investigation of the concrete measures regarding intergovernmental relationships reforming in direction of their decentralization, and in the formation of the well-balanced economic and innovative policies.

Keywords: decentralization, innovative economic growth, innovative state management, intergovernmental relationships, panel data analysis, U-shape hypothesis testing.

Introduction. Under conditions of the innovative development intensification at the supranational level and fast moral ageing of main means and technologies, the priority task in the formation of the economic policy at the country's and regional levels is to provide the development of innovations. That is the reason

Cite as: Vasylieva, T., Harust, Yu., Vinnichenko, N., \& Vysochyna, A. (2018). Optimization of the financial decentralization level as an instrument for the country's innovative economic development regulation. Marketing and Management of Innovations, 4, 381390. http://doi.org/10.21272/mmi.2018.4-33 

Instrument for the Country's Innovative Economic Development Regulation

why the innovative constituent has to be the essential element of the state regulation. Thus, it is not without reason that intergovernmental relationships have to be transformed taking into account the priorities of the innovative economic development provision. Particularly, the financial decentralization reform should provide not only the optimal distribution of powers and incomes between budgets of different levels but first of all, to stimulate the local self-government authorities to make more effective managerial decisions regarding the available financial resources using to implement the projects with stable economic results. So, the efficiency of the financial decentralization reforms under modern realities has to be defined not due to the progress regarding the increase of the financial autonomy and subnational formations' independence level, but through the intensity of the economic system innovative restructuring in the region and in the country. Such an approach is quite logical because orienting of the local budget incomes to extend the current functions financing cannot guarantee the longterm positive effect, whereas investment in the innovative activity development in the region enables to move on to the intensive progressive economic growth. Taking into account the priority necessity to use the financial resources in terms of the decentralization, it is urgent to define the optimal level of the expenditure decentralization considering the goals of the innovative economic development. However, it is traditionally well-known to consider the decentralization among scientists as a positive or negative phenomenon (the character of the effect from the decentralization impact depends on the final variable, and countries which are included to the selected group). However, just this pluralism and ambiguity of scientific views cause the necessity to find the innovative mechanisms to identify the financial decentralization optimal level, which will take into account the dual nature of the investigated phenomenon.

Literature Review. A lot of scientific studies observe the financial decentralization role in the process to provide the innovations development and economic growth in the country. Many leading economists point out the positive effect from decentralization, which consists in increasing of the public service quality, stimulating to develop the competitive relationships between different regions, increasing of the local budgets formation system accountability, optimization of the financial resources allocation (particularly, their investment in the projects, which promote the qualitative transformation of the subnational formations' economic system thanks to the innovative technologies) etc.

The scientific literature has a lot of studies, which prove the positive effect of decentralization at the theoretical and empirical levels in terms of the development of the innovation. Particularly, Salmon (1987) emphasizes that one of the important positive decentralization results is to improve the business activity level among the regional economic subjects thanks to the expansion of access to new technologies, and as a result, to the activation of the innovative development in the relevant territory and state as a whole. Martinez-Vazquez and McNab (2003) distinguish this decentralization effect in their research. Capuno (2011) in the context of the local innovations' development driver's identification in the Philippines (based on the analysis of 209 innovations, introduced in 48 cities) empirically confirm that decentralization is one of the significant tools to increase the innovative activity. Vasylieva \& Kasyanenko (2013) single out decentralization as one of the determinants of the country's innovative potential growth. Besides, Zupan, Pustovrh, \& Cankar (2017), studying the decentralization impact on the state's innovative potential, point out that expenditure decentralization help to develop the infrastructure, which together with other economic factors, enables to provide the highest degree of the scientific and innovative activity.

Singh (2018), analysing the regional disproportions and preconditions of the sustainable economic development in India, notes that the investment activity extension at the administrative formations level (especially in the innovative projects) acts as a trigger of the sustainable economic growth.

At the same time, most scientists do not focus their attention on the development of innovations by means of decentralization but identify its impact on economic development as a whole. In the research Chygryn et al. (2018) on the basis of the panel data regression analysis for selected European countries empirically confirms positive impact of the financial decentralization indices on various social and 

Instrument for the Country's Innovative Economic Development Regulation

economic development parameters, such as GDP (US dollars), GDP growth, inflation level, net inflow of direct foreign investment. However, the statistically significant negative effect is revealed after the decentralization processes extension on the export-import operations dynamics, gross national income and unemployment level. Slavinskaite (2017) gains the ambiguous empirical results regarding the impact of fiscal decentralization level on economic growth. The financial decentralization concept was formed as a composite indicator of 4 constituents: decentralization index of expenditure, incomes, debts, and amount of transfers by local self-government authorities. The final variable is GDP per capita. The block of control variables is the ratio between investment amount and GDP, the economic structure index, the index of human capital development (expenses for education), an indicator of the technological development, level of the citizens' employment. The research was carried out using regression analysis tools of panel data during 2005-2014 for selected European countries. Particularly, according to the results of the empirical study, the author points out statistically significant and positive effect for economic growth in extension of decentralized processes scale in EU-21 countries and in the countries with lower level of the economic development (Bulgaria, Croatia, Cyprus, the Czech Republic, Estonia, Latvia, Lithuania, Hungary, Poland, Portugal, Slovakia, Slovenia, Romania), however, statistically insignificant influence for more developed countries (Denmark, Finland, France, Ireland, Italy, Holland, Sweden, Great Britain). However, despite studies, which underline the positive effect of decentralization both at the theoretical and empirical levels, some scientists, among which Rodriguez \& Gill (2005), Rodden (2003) find great decentralization risks, among which there are increase of the budget deficit probability, subjects' interests lobbying, decrease of managerial decision quality, corruption, regional misbalances and others. All determined factors may negatively influence not only the local budget but also the economic development of regions and state. Besides, Rodríguez-Pose \& Krøijer (2009) empirically confirmed the statistically significant negative impact of the financial decentralization on the economic growth in countries of Central and Eastern Europe. The GDP growth per capita is selected as the final variable; factorial - expenditure decentralization level, calculated as a ratio between expenses at the subnational level and total expenses; the control variables block includes population growth, basic level of GDP (1990), ratio of investments to GDP, GDP deflator, number of computers per 1000 inhabitants, indicator of human capital development. The statistically significant negative impact of the factorial feature on the final variable was fixed both in the model specification without lags, and with lags (up to 8 periods inclusive).

Thus, taking into account great potential to use financial decentralization as an innovative policy instrument, and scientists' positions ambiguity regarding its impact on the economic development, there is a necessity to carry out empirical studies to find an optimal level of decentralization in terms of the state's innovative economic development provision using tools, which enable to consider the dual nature of such impact.

Methodology and research methods. Thus, it is necessary to describe the main input parameters, which will be used to test the hypothesis regarding the non-linear dependence of the innovative economic growth on the expenditure decentralization. Particularly, the time diapason of the research comprises the interval 2002-2015, which is greatly caused by the accessibility of the necessary statistic information. There are 23 states, members of the Organization for Economic Cooperation and Development, which are selected for the study. One should mention that membership in this organization provides construction of national economy on the competitive, democratic and liberal basis. It enables to confirm that there is an innovative approach to solve important economic problems. This group of countries includes high developed states and post-socialist states, and that is why it has sufficient differentiation level to obtain adequate results. The analysis will be carried out for such countries as Austria, Belgium, Canada, Czech Republic, Denmark, Estonia, Finland, France, Germany, Greece, Hungary, Italy, Netherlands, Norway, Poland, Portugal, Slovakia, Slovenia, Spain, Sweden, Switzerland, United Kingdom and the United States. In terms of the factorial, final and control variables selection, the key task is to form such indicators array, 

Instrument for the Country's Innovative Economic Development Regulation

which will suit the comparability and informativity principles, and, so, will help to reach the maximum available time horizon, since this criterion is one of the decisive criteria, which influence the obtained results.

Thus, GDP per capita, which is traditionally used by western scientists in the empirical decisions, oriented to define the relevant factors of the country's economic growth, is used as the final variable. The chosen parameter enables to estimate the innovative constituent of the economic policy, since the GDP growth per capita is practically impossible to provide through using of extensive mechanisms (since deployment of the production amounts is followed by expenses increase, size of which often exceeds the result), but only on the basis of innovative mechanisms, which demand great startup capital expenditures, however let to receive stable positive economic effect in future.

The identification of the factorial variable, which will express the financial decentralization level, is a more complicated task, caused by the absence of consensus among researchers in this area. Woller and Phillips (1998) propose to define the financial decentralization level by one of the following indices: ratio of the local budgets' incomes and total incomes; ratio of incomes without intergovernmental transfers and total incomes; ratio of the local budget expenditures and total expenditures; ratio of the local budgets' expenditures and total expenditures, reduced by the amount of the social expenditures. At the same time, Davoodi and Zou (1998) also identify the decentralization indicator as the ratio between local and state budgets incomes. Hanh, Diep, and Shin (2014) find the level of financial decentralization using the following indicators: the ratio of local budgets incomes and their expenditures; ratio of local budgets expenditures and public expenditures of the state budget. Salo (2013) in his research distinguishes the incomes decentralization index (ratio of the local budgets incomes without intergovernmental transfers and the consolidated budget revenues), expenditures decentralization (ratio of the local budgets expenditures and consolidated budget expenditures without intergovernmental transfers), general decentralization (average value of two above indicators). Taking into account the fact that incomes decentralization takes place more progressively and comprises a wider set of instruments, and therefore, has been reflected in most publications, within the framework of this study, the emphasis will be placed on the expenditures decentralization, since today the problem of the optimal redistribution of powers between budget system levels, and rationalization of these funds spending at the level of the administrative formation (particularly, prioritization of costs in favour of innovative investment) is a key aspect, over solution of which scientists and practitioners are still working.

Thus, the parameter, which shows the expenditures decentralization level is an index (variable marker - Exp), which is calculated as a ratio of the consolidated expenses amount at the subnational level and the state's consolidated expenses, expressed in part of the whole. According to the OECD methodology, the consolidated expenses in every level of the state regulation are defined as the total sum of expenses without intergovernmental transfers from the budget of the relevant level. Therefore, this approach, used within the framework of this study, totally corresponds the approach regarding the financial decentralization degree, proposed by the International Monetary Fund (2018) and by the Organization of Economic Cooperation and Development (OECD) (2018).

This research also comprises a wide set of control variables, the combination of which will be identified by the orientation to achieve maximum adequacy of the obtained results in the relevant iterations of the model. First of all, it is necessary to notice that implementation to the control variables regression model enables to increase the general level of the model adequacy, since the regression dependence between two indicators may lead to false results, whereas the including of additional parameters, which explain patterns regarding the effective feature change and have strong relationship with it, to the model, that enables to receive statistically significant coefficients, which show the regularities in the economic and innovative processes development (Ilvento, 2005). Therefore, within the framework of the mentioned stage, there is a necessity to specify the control variables, which will have a strong relationship with final 
variable - the value of GDP per capita (US dollars). In order to implement the mentioned stage, the correlation analysis was carried out. According to its results, the control variables were formed. The control variables include only those indices which have a strong relationship with an effective feature in accordance with the Cheddok scale (the correlation coefficient is over 0.7 ). The variables, by which the models were tested, include:

- deficit / proficient of the budget in relation to GDP, \% (Def) ) is one of the main parameters, which may be used to evaluate the efficiency of the budget and financial policy, and also perspectives regarding the state's debt security change;

- consumer price index (2010 - 100\%) (CPI) is a parameter, which demonstrates the price stability of the country's economy;

- level of the citizens' employment, calculated as the share of employed citizens to the total population in the country in \% (Empl) is a parameter, which describes the labour potential of the national economy;

- the share of expenditures for final consumption in GDP, \% (ConsExp) enables to consider the citizens' living standards;

- the share of direct foreign investment in GDP, \% (FDI) and share of the gross capital formation in GDP, \% (GFCF) describe the state's investment and innovative potential;

- the index of economic openness (ratio of total export and import amount to GDP), \% (Trade) enables to evaluate the country's international activity potential.

The adequacy to select the control variables is also confirmed by their wide popularity in other publications, oriented to reveal the triggers of the innovative economic growth. Vasylieva et al. (2018) and Lyeonov, Vasylieva, and Lyulyov (2018) investigating the macroeconomic stability impact on the economic growth, empirically prove the statistically significant impact of such factors as foreign investment, citizens' employment and economic openness on GDP per capita. Szarowská (2017), Andrejovská A., \& Puliková V. (2018) also empirically prove a high level of GDP correlation with such indices as direct foreign investment and citizens' employment. Bhowmik (2018) empirically confirms the positive impact of direct foreign investment of GDP, whereas Nguedie (2018) shows the non-linear form of the dependence between these variables. Hüseyni, Eren \& Çelik (2017), in their turn, confirm the statistically valuable positive impact of the gross capital formation extension on GDP. Tung (2018), using OLS regression, empirically proves the statistically significant negative impact of the deficit on GDP change (direct foreign investment in the model act as a control variable). Harold (2018) proves the relationship between amounts of foreign trade and economic growth. Bilan et al. (2018) include inflation and direct foreign investment to the control variables block in the study. The informational base of the research includes official data, represented on sites of OCD and World Bank group. Having characterized the main parameter, which will be used within this empirical research, it is reasonable to describe its stages. First of all, we will carry out the U-shape hypothesis testing and variables dependence. One should also mention that input data is formed in terms of countries, years and concrete indicators, the i.e. calculation will be performed for panel data, that preconditions to use more complicated econometric tools of such data analysis. In order to check the U-shape dependence between final and factorial variables, it is suggested to use mathematical, graphical and econometric methods.

Thus, the base of the mathematical and econometric methods is to construct the regression dependence, which in this case is represented as:

$$
G D P=\alpha+\gamma E x p+\mu E x p^{2}+\sum_{i=1}^{n} \beta_{i} X_{i}+\varepsilon
$$

where GDP-GDP per capita; Exp - an indicator of the financial decentralization level; $X_{i}-$ set of the control variables; $\mathcal{E}$-standard error. 
T. Vasylieva, Yu. Harust, N. Vinnichenko, A. Vysochyna. Optimization of the Financial Decentralization Level as an Instrument for the Country's Innovative Economic Development Regulation

While using equation 1 , one can find the function extremum:

$$
\operatorname{Exp}_{\text {ext }}=-\frac{\gamma}{2 \mu}
$$

where $E x p_{\text {ext }}$ is an optimal level of the financial decentralization; $\gamma$ - coefficient of the regression model with variable Exp; $\mu$-coefficient of the regression model with variable Exp?

The equation 2 may notice that the extremum point will be positive (it is an obligatory condition in this study since the financial decentralization level cannot be negative) only if coefficients $\mu$ and $\gamma$ have different signs. Beside the mentioned condition, these coefficients have to be effective (it means that they must be significant, at least at the confidential interval in $90 \%$ ), the defined extremum point belongs to the value range of the factorial feature. Thus, the fulfilment of the above conditions is a base to confirm the hypothesis regarding quadratic dependence between variables (Lind \& Mehlum, 2007). However, to obtain adequate results, we use the Generalized Linear Model, rather than the regression model by the method of the least squares (OLS and GLS regressions), since it enables to evaluate dependencies with linear and non-linear nature. This project will be implemented through using of the command «glm» of the software complex Stata 12/SE. Testing of the hypothesis regarding the graphical method used provides a construction of the graphic with command «qfit» of the software complex Stata 12/SE.

Results. Thus, let us come to the implementation of the mentioned stages. The using of econometric and mathematical methods enable to obtain the following results demonstrated in table 1.

Table 1 - Results of the regression analysis regarding the expenditure decentralization level impact on the selected countries' economic development

\begin{tabular}{|c|c|c|c|c|c|c|c|c|c|}
\hline Variable & Coefficient & $\begin{array}{c}\text { Standard } \\
\text { error }\end{array}$ & $\mathbf{Z}$ & $\mathbf{P}>\mathbf{| z |}$ & Variable & Coefficient & $\begin{array}{c}\text { Standard } \\
\text { error }\end{array}$ & $\mathbf{Z}$ & $\mathbf{P}>|\mathbf{z}|$ \\
\hline Exp & 15182.43 & 4962.11 & 3.06 & 0.002 & ConsExp & -780.34 & 208.33 & -3.75 & 0.000 \\
\hline Exp $^{2}$ & -5635.37 & 2380.55 & -2.37 & 0.018 & FDI & 168.31 & 66.22 & 2.54 & 0.011 \\
\hline Def & 687.02 & 218.19 & 3.15 & 0.002 & GFCF & 202.96 & 202.96 & -5.43 & 0.000 \\
\hline CPI & 839.22 & 82.24 & 10.21 & 0.000 & Trade & -156.54 & 23.46 & -6.67 & 0.000 \\
\hline Empl & 438.52 & 146.68 & 2.99 & 0.003 & Const & 32815.12 & 23800.93 & 1.96 & 0.050 \\
\hline
\end{tabular}

Sources: developed by the authors

Based on the data from table 1, it is possible to make the following conclusions: statistical significance and difference of signs with independent variable model and square of the independent variable enables to affirm the confirm U-shape dependence between dependent and independent variables; all control variable of model is statistically significant at the $99 \%$ and $95 \%$ confidence intervals.

The next stage of this study is to use test with the purpose to confirm U-shape dependence and determination of the extremum point. The results of the command "utest", that is a superstructure of the software complex Stata 12/SE is shown in table 2.

Thus, based on the data, demonstrated in table 2, one may confirm the square form of the dependence between investigated parameters, which has the inverse $U$-shape (since $P>|t|$ or general test is less than 0.05 , it enables to reject zero hypothesis and to confirm the alternative hypothesis). The parabola extremum point belongs to the set of values of the factorial feature and is 1.35, i.e., for studied selected countries GDP maximization per capita is achieved when the expenditures decentralization level is 1.35. 
T. Vasylieva, Yu. Harust, N. Vinnichenko, A. Vysochyna. Optimization of the Financial Decentralization Level as an Instrument for the Country's Innovative Economic Development Regulation

Table 2 - Results of the test to confirm the quadratic form of dependence between indices of the expenditure decentralization level and GDP per capita for all selected countries

\begin{tabular}{|l|l|l|}
\hline Specification of the model & $\mathrm{f}(\mathrm{x})=\mathrm{x}^{\wedge} 2$ \\
\hline Hypothesis & $\begin{array}{l}\mathrm{H} 0: \text { dependence is monotone or } \\
\text { has U-shape }\end{array}$ & $\begin{array}{l}\mathrm{H} 1 \text { : dependence has an inverse U- } \\
\text { shape }\end{array}$ \\
\hline & Lower limit & Upper limit \\
\hline Interval & 0.06 & 2.25 \\
\hline Angel & 14506.19 & -10176.74 \\
\hline $\mathbf{t}-\mathbf{v a l u e}$ & 3.093 & -1.661 \\
\hline $\mathbf{P}>|\mathbf{t}|$ & 0.0011 & 0.0489 \\
\hline General results of the test $(\mathbf{P}>|\mathbf{t}|)$ & 0.0489 & \multicolumn{2}{|l|}{} \\
\hline The extremum point & 1.35 & \multicolumn{2}{|l|}{} \\
\hline
\end{tabular}

Sources: developed by the authors

The finalization of this stage in the research provides using of the graphical method to confirm the results, obtained earlier. Particularly, this stage involves the construction of the graph, which describes the set of the factorial and final variables, indicated by points, and integration to the graph of the additional function, which characterizes non-linear dependence between these variables (graphical interpretation of the regression equation). Results are shown in fig. 1.

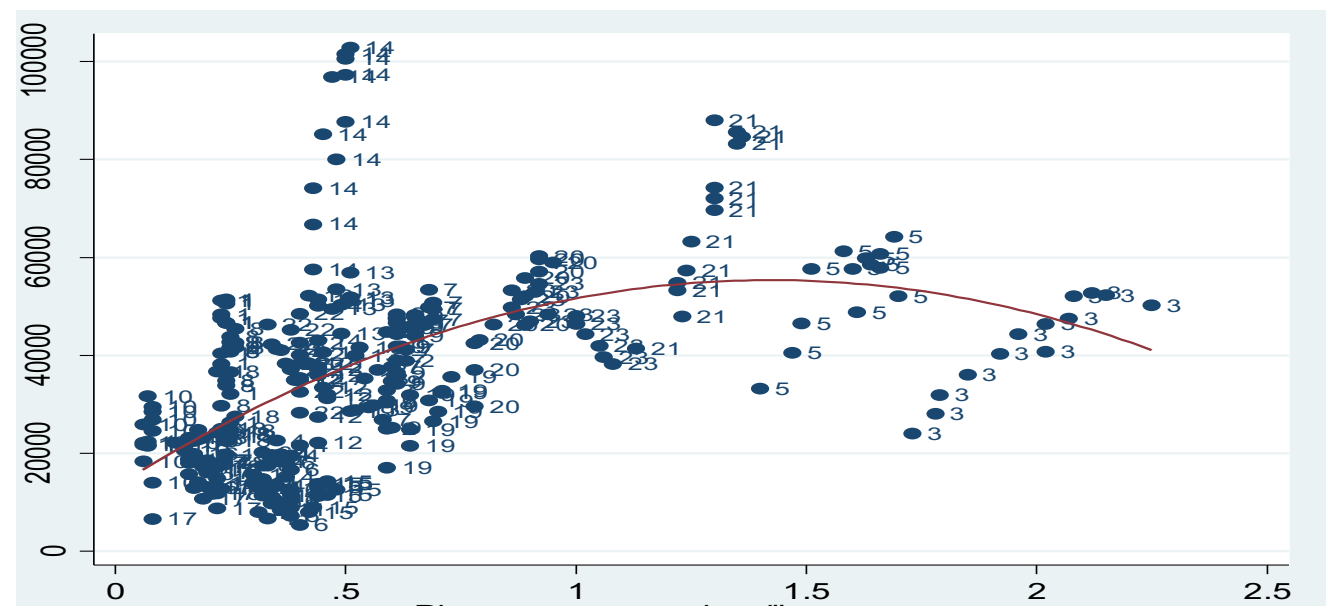

Figure 1 - Graphical interpretation of dependence between expenditures decentralization level index and GDP per capita for all selected countries

\section{Sources: developed by the authors}

Thus, the graphical method also confirms the results, obtained from using of the econometric and mathematical methods, namely: the inverse U-shape dependence of the GDP change per capita on the expenditures decentralization level change, and the achievement of maximum function extremum in the point with expenditures decentralization level 1.35.

Conclusions. At the modern stage of the economic relations development, the innovative activity takes a prominent place among the main determinants of the competitiveness of the national economy and some administrative units. That is why the basic targets of the economic policy at different levels of 

Instrument for the Country's Innovative Economic Development Regulation

its implementation should be the promotion of the innovative development. The attention should be paid not only to the innovative constituent in terms of the general economic strategy, but its separate elements. Particularly, the intergovernmental relationship reforming process has to take into account the priorities of the state's innovative strategy. The financial decentralization reform, as one of the main directions regarding the qualitative change of the intergovernmental relationship, will be effective only if the main strategic goal of this process is not only the subnational formations' financial autonomy but also the innovative economic growth stimulation owing to the financial resources' allocation optimization into more innovative and stable projects. That is why, the important task, the empirical solving of which becomes urgent, is to define the optimal level of the expenditures decentralization as a tool to provide innovative economic growth

The use of GLM tools to test the hypothesis regarding the dual nature of the financial decentralization impact (particularly, expenditures decentralization) on parameters of the innovative economic development let to confirm the proposed hypothesis. In particular, all three methods (econometrics, mathematical and graphical) prove the fact that the maximum level of GDP per capita may be achieved if the expenditures decentralization level is 1.35, i.e., growth of the indicator above the defined extremum will worsen the economic dynamics and innovative activity, and that is why the excessive expenditure on subnational budgets is an inhibitor of the sustainable economic growth. Taking into account the international context of this study (in the selected countries with different development level), the obtained results are universal and may be effective guide on the way to optimize the distribution of the expenditure powers between different levels of the budget system in the world countries, so it proves their innovativeness, theoretical and practical significance. Besides, the obtained results prove that local selfgovernment authorities are able to finance the important investment projects at the local level in larger amounts than using state budget funds, since the optimal level of expenditure decentralization is more than 1, i.e. the consolidated expenditures amount at the subnational level is higher than the analogical indicator in the country. Such a situation enables to conclude that the innovation activity is possible in direction "bottom-up", but it is necessary to form the optimal income base for local budgets and reorient the structure of expenditure powers distribution in such a way that to finance the current expenditures mostly at the state level, whereas at the local level to create the preconditions to extend the capital innovation-oriented expenditures. Such a situation will enable to provide higher efficiency of the decentralization reform and will provide sustainable innovative economic development.

In the context of the further studies, the promising area is to identify the impact of various decentralization demonstration on the concrete tools to provide the sustainable and innovative economic growth, that lets to find the most sensitive channels of impact on the mentioned processes.

Funding: The research is carried out within the framework of the following SRW: "Modelling and prediction of the social and economic and political road map of reforms in Ukraine to move to the sustainable growth model" (number of the state registration 0118U003569), "The new innovative model conception of the state regulation regarding the financial system in Ukraine" (number of the state registration 0118U003582) and "Development of scientific and methodological foundations and practical tools of financial policy of sustainable development of united territorial communities" (number of the state registration 0117U003935).

\section{References}

Andrejovská, A., \& Puliková, V. (2018). Tax Revenues in the Context of Economic Determinants. Montenegrin Journal of Economics, 14 (1), 133-141. DOI: 10.14254/1800-5845/2018.14-1.10

Bach, S., Blochliger, H., \& Wallau, D. (2009). The spending power of sub-central governments: a pilot study. Retrieved from https://www.oecd.org/tax/federalism/42783063.pdf 
T. Vasylieva, Yu. Harust, N. Vinnichenko, A. Vysochyna. Optimization of the Financial Decentralization Level as an Instrument for the Country's Innovative Economic Development Regulation

Bhowmik, D. (2018). Financial Crises and Nexus Between Economic Growth and Foreign Direct Investment. Financial Markets, Institutions and Risks, 2(1), 58-74. DOI: 10.21272/fmir.2(1).58-74.2018

Bilan, Y., Lyeonov, S., Vasylieva, T., Samusevych, Y. (2018). Does tax competition for capital define entrepreneurship trends in Eastern Europe? On-line Journal Modelling the New Europe, 27, 34-66. DOI: 10.24193/OJMNE.2018.27.02

Blochliger, H., \& King, D. (2006) Fiscal autonomy of sub-central governments. Retrieved from https://www.oecd.org/ctp/federalism/37388375.pdf

Capuno, J. J. (2011). Incumbents and innovations under decentralization: An empirical exploration of selected local governments in the Philippines. Asian Journal of Political Science, 19 (1), 48-73.

Chygryn, O., Petrushenko, Y., Vysochyna, A. \& Vorontsova, A. (2018). Assessment of Fiscal Decentralization Influence on Social and Economic Development. Montenegrin Journal of Economics, 14 (4), 069-084. DOI: 10.14254/1800-5845/2018.14-3.5

Davoodi, H., \& Zou, H. F. (1998). Fiscal decentralization and economic growth: A cross-country study. Journal of Urban Economic, 43, 244-257.

Dziobek, C., Gutierrez Mangas, C., \& Kufa, P. (2011). Measuring Fiscal Decentralization-Exploring the IMF's Databases. USA, Washington, DC: International Monetary Fund.

Hanh, N., Diep, P., \& Shin, H. (2014). The Optimal Point for Fiscal Decentralization. European Journal of Business and Management, 6 (20), 182-189.

Harold, N. Ng. Yan. (2018). Econometric analysis of long and short-run effects of exports on economic growth in Cameroon (1980-2016). Financial Markets, Institutions and Risks, 21), 50-57. DOI: 10.21272/fmir.2(1).50-57.2018

Hüseyni, I., Eren, M., \& Celik, A. K. (2017). Examining the Relationship Among Economic Growth, Exports and Total Productivity for OECD Countries Using Data Envelopment Analysis and Panel Data Analyses. Montenegrin Journal of Economics, 13 (3), 63-73.

DOI: 10.14254/1800-5845/2017.13-3.6

Ilvento, T. (2005). Using Statistical Data to Make Decisions: Multiple Regression Analysis. Retrieved from http://www.udel.edu/FREC/ ilvento/BUAD820/MOD504.pdf.

Lind, J. T., \& Mehlum, H. (2007). With or Without U? - The appropriate test for a U shaped relationship. MPRA, 4823, 1-12.

Lyeonov, S., Vasylieva, T., and Lyulyov O. (2018). Macroeconomic stability evaluation in countries of lower-middle income.

Bulletin of the National Mining University, 1, 138-146.

Martinez-Vazquez, J., \& McNab, R. (2003). Fiscal Decentralization and Economic Growth. World Development, 31(9), 1597 1616.

Nguedie, Y. H. N. (2018). Corruption, Investment and Economic Growth in Developing Countries: A Panel Smooth Transition Regression Approach. SocioEconomic Challenges, 2(1), 63-68. DOI: 10.21272/sec.2(1).63-68.2018
OECD
Fiscal
Decentralisation
Database
(2018)
Retrieved
from

$\mathrm{http}: / / \mathrm{www}$. oecd.org/ctp/federalism/oecdfiscaldecentralisationdatabase.htm\#C_Title. 729

Rodden, J. (2003). Reviving Leviathan: Fiscal federalism and the growth of government. International Organization, 57,695-

Rodriguez, P. A., \& Gill, N. (2005) On the economic dividend of devolution. Regional Studies, 39 (4), 405-420.

Rodriguez-Pose, A., \& Krøijer, A. (2009) Fiscal Decentralization and Economic Growth in Central and Eastern Europe.

Retrieved from http://www.Ise.ac.uk/europeanInstitute/LEQS\%20Discussion\%20Paper\%20Series/LEQSPaper12.pdf

Salmon, P. (1987). Decentralizations as an Incentive Scheme. Oxford Review of Economic Policy, 3 (2), 24-43.

Salo, T. V. (2013). Decentralizatsiia finansovoii systemy: stan ta otsinka rivnia v Ukraini [Decentralization of financial system: state and assessment in Ukraine]. Efektyvnist derzhavnoho upravlinnia - Efficiency of public administration, 35, 324-330 [in Ukrainian].

Singh, S.N. (2018). Regional Disparity and Sustainable Development in NorthEastern States of India: A Policy Perspective. SocioEconomic Challenges, 2(2), 41-48. DOI: 10.21272/sec.2(2).41-48.2018

Slavinskaite, N. (2017). Fiscal decentralization and economic growth in selected European countriesJournal of Business Economics and Management, 18(4), 745-757. doi:10.3846/16111699.2017.1292312

Szarowská, I., (2017). Does public R\&D expenditure matter for economic growth? GMM approach. Journal of International Studies, 10(2), 90-103. doi:10.14254/2071-8330.2017/10-2/6

Tung, L. T. (2018). The effect of fiscal deficit on economic growth in an emerging economy: Evidence from Vietnam. Journal of International Studies, 11(3), 191-203. doi:10.14254/2071-8330.2018/11-3/16

Vasylieva, T. \& Kasyanenko, V. (2013). Integral assessment of innovation potential of Ukraine's national economy: A scientific methodological approach and practical calculations. Actual Problems of Economics, 144 (6), 50-59.

Vasylieva, T., Lyeonov, S., Lyulyov O., and Kyrychenko K. (2018). Macroeconomic Stability and Its Impact on the Economic Growth of the Country. Montenegrin Journal of Economics, 14 (1), 159-170. DOI: 10.14254/1800-5845/2018.14-1.12

Woller, G., \& Phillips, K. (1998). Fiscal decentralization and LDC economic growth: An empirical investigation. Journal of Development Studies, 34 (4), 139-148.

World DataBank (2018) Retrieved from http://databank.worldbank.org/data/home.aspx

Zupan, B., Pustovrh, A., \& Cankar S. S. (2017). Does Decentralized Governance Lead to Less Scientific Output? A Fuzzy Set Analysis of Fiscal Decentralization and Determinants of National Innovation Capacity. Journal of Local Self-Government, 15(3), 647 668. DOI: https://doi.org/10.4335/15.3.647-668(2017) 
T. Vasylieva, Yu. Harust, N. Vinnichenko, A. Vysochyna. Optimization of the Financial Decentralization Level as an Instrument for the Country's Innovative Economic Development Regulation

T. А. Васильєва, д.е.н., професор, Сумський державний університет (Україна);

ю. В. Гаруст, д.юр.н., доцент, Сумський державний університет (Україна);

Н. В. Винниченко, д.е.н., доцент, Сумський державний університет (Україна);

А. В. Височина, к.е.н., Сумський державний університет (Україна).

Оптимізація рівня фінансової децентралізації як інструмент управління інноваційним економічним розвитком країни

Ця стаття узагальнює аргументи та контраргументи в межах наукової дискусії щодо визначення оптимального рівня децентралізації, який би сприяв забезпеченню інноваційного розвитку країни, адже ключовим завданням децентралізації має бути не лише розширення дохідних та видаткових повноважень субнаціональних утворень, а й розуміння фінальної мети цього процесу - якісної трансформації економічноі системи країни у напрямку поліпшення ії інноваційності та конкурентоспроможності. Таким чином, реформа децентралізації повинна виступати драйвером інноваційного економічного розвитку, що $є$ закономірним результатом збільшення свободи прийняття управлінських рішень на локальному рівні, зростання фінансовоі самодостатності субнаціональних утворень та більш ефеективної видаткової політики (розширення обсягів фінансування інноваційних проектів, що сприятиме сталому економічному зростанню). Систематизація наукових напрацювань з означеної проблематики засвідчила, що серед науковців не існує одностайності щодо впливу децентралізації на економічний та інноваційний розвиток країни, а тому актуальності набуває продовження емпіричних пошуків у даному напрямку, що дозволили б врахувати дуальну природу наслідків активізації децентралізаційних процесів. Емпіричне дослідження проведено з використання інструментарію аналізу нелінійної форми залежності (GLM регресія, яка дозволяє ідентифікувати як лінійний, так і нелінійних характер взаємозв'язку між змінними) на основі панельних даних, сформованих для вибірки 23 держав-членів OЕCP (Австрія, Бельгія, Канада, Чеська Республіка, Данія, Естонія, Фінляндія, Франція, Німеччина, Греція, Угорщина, Італія, Нідерланди, Норвегія, Польща, Португалія, Словаччина, Словенія, Іспанія, Швеція, Швейцарія, Великобританія та США) за 2002-2015 рр. У якості факторної змінної моделі було обрано показник децентралізації витрат, який розраховується як співвідношення обсягу консолідованих витрат на субнаціональному рівні до обсягу консолідованих витрат держави, вираженого у частинах цілого. Результативна змінна (традиційна для моделей економічного росту) - ВВП на душу населення (дол. США). Крім того, до даної регресійної моделі було введено набір контрольних змінних (що пояснюють закономірності зміни результативної ознаки та мають сильний зв'язок з нею). Вибір контрольних змінних було проведено на основі використанням кореляційного аналізу. Практична реалізація усіх етапів даного дослідження була здійснена з використання програмного продукту Stata 12/SE. За результатами дослідження було підтверджено нелінійний характер залежності (форма оберненої параболи) зміни ВВП на душу населення від зміни рівня децентралізації витрат, а також досягнення максимального екстремуму функції у точці з рівнем децентралізації витрат 1,35, тобто надмірне видаткове навантаження (понад означений поріг) на місцеві бюджети супроводжуватиметься пригніченням інноваційної та економічної динаміки, що має бути враховано відповідними уповноваженими органами виконавчої гілки влади при розробці конкретних заходів щодо реформування міжбюджетних відносин у напрямку їх децентралізації, а також при побудові виваженої економічної та інноваційної політик.

Ключові слова: аналіз панельних даних, державний менеджмент інновацій, децентралізація, інноваційне економічне зростання, міжбюджетні відносини, тестування гіпотези щодо квадратичної форми залежності.

Manuscript received:

(c) The author(s) 2018. This article is published with open access at Sumy State University. 